\title{
Revitalization of Value and Meaning Toba Batak Folklore in the Formation of Character Education of Children
}

\author{
${ }^{1}$ Ratih Baiduri, ${ }^{2}$ Leylia Khairani \\ ${ }^{1}$ Departement of Anthropology Education \\ Universitas Negeri Medan \\ Medan, Indonesia \\ 2Department of Hospitality \\ Sahid Institute of Tourism \\ Jakarta, Indonesia \\ ratihbaiduri215@gmail.com
}

\begin{abstract}
Folklore originated from the oral tradition of society, full of messages of value and morals to be conveyed in one generation to the next generation. Folklore can be used as a means to guide children to behave well because it contains many pieces of advice that can be used as life lessons.This study aims to: (1) describe the meaning and value of the Toba Batak folklore entitled The Polite Source of Life, Not Caring for the Source of Destruction (2) revitalizes the Toba Batak folklore to be implemented in the formation of character education of children. The research method using the qualitative method with the descriptive approach. Data collection techniques include literature studies and in-depth interviews. Informants selected purposively who are experts about the Toba Batak folklore. Nevertheless, today the phenomenon that occurs in society, especially the younger generation no longer recognize the values contained in folklore. Also, the school also does not include folklore become part of learning. From the research results obtained that the Toba Batak folklore is full of character education values to form noble moral behavior. The values are, charge, concern, obedient to the parents, not arrogant or humble, helping others, respecting others, sincere, be fair and no strings attached. Revitalization of the values contained in this folklore can be done by preserving and transforming it to the young generation in the form of education, especially in the local content curriculum, extracurricular activities in the form of theater/drama and film/video making.
\end{abstract}

Keywords: Revitalization, Toba Batak folklore, the establishment of character education of children, values , and meaning

\section{INTRODUCTION}

The present orientation of education leads to a mechanical educational phenomenon, aimed only academic achievement. This is evident throughout the learning system applied to early childhood (about 4-6 years). Children from preschool age have been confronted with ahard skill-oriented learning condition that is the ability to recognize letters, numbers, and even spell a word. Of course, this is not by the mandate of the National Education System Act Number of the System of 2003, which states that one of the goals of national education is to develop the potential of learners to have intelligence, personality, and noble character. With such a mechanical education system, will result in education only as the generation of logic-only generation. To achieve the goal of national education that not only expands the potential of students who are intelligent logic but also has a noble personality and character must necessarily be accompanied by a learning system that has a content value of character education. It is moreover, reinforced by Saefuddin[1] that character education in our education (Indonesia) since primary education is very weak, our education world is too leaping into the components of science and technology. This is very worrying, because the competence ofsoft skillsrelated to ethics, behavior, emotional management, personality, morale, and persistence, will bring the child's success in social life in the future. Thus since primary education should be more children's education focused on character education. As expressed by Erikson in Papaliaet al., [2] and Brewer [3] that the success of children overcoming conflict at an early age determines the success of children in social life in later adulthood. Roosevelt in Lickona [4] says, "to educate a person just to think with reason without moral education means to build a threat against the life of society." This shows how importantethical education and character building from an early age. 


\section{VITALIZATION OF TOBA BATAK FOLKLORE AS Character Education Media For CHILDREN}

The noble character planting associated with character formation that contains ethics in children is not only limited to understanding but needs to be implemented in everyday life. Good ethical planting will shape the characters, attitudes, and behaviors that strengthensoft skillsin instilling excellent habits. In Indonesia, character education in education since elementary education is very weak. The education world is too leaping into the components of science and technology. Weak character education will lead to soft skill competence does not grow in children.Soft skillcompetencies related to ethics, behavior, emotional management, personality, morale, and persistence, will bring the child's success in social life in the future. Thus since earlychildhood education, children should be more focused on character education to formsoft skills to produce quality character to the nation.

Children's interest in folklore today is lacking because, in their daily environment, they also do not find family members in the family and school environment that tell stories or folklore to them. Children are closer to a technology-based game system packaged insmart phonesorgadgets.Therefore, strategic and planned steps can be taken by utilizing the role of formal education institution of Kindergarten as apublic education institution. The important step taken is to revitalize local folklore.

The values often raised in folklore are the value of education. Folklore reflects the view of life in the form of truth values that serve as life guidance in society. Therefore, folklore that contains the values of local wisdom is potentially explored to be used as a media orrole modelfor the application to the value of character education. The values of localized wisdom are very implementation because they fit the sociocultural context of their community.

The model of therevitalization of folklore in schools can be done by incorporating this folklore in localized content learning such as subjects of noble character,or that is packed with interesting and fun learning models. With autonomy given to schoolsshould be free to make policies to be able to form learners have a good character. Also, the content of this folklore can be integrated into various other subjects, which provide space for the formation of children's character such as literature subjects in the subjects of Bahasa Indonesia, Integrated IPS and Civics. In addition to integrating it with a relevant theme in a particular subject, revitalizing folklore can be done by incorporating the content of this folklore into extracurricular activities such as theater or film activities. In general,theseactivities conducted in schools aim to train the formation of children's character. The activity of a theater or film is an activity process that involves the child directly to cultivate creativity in activities that include the preparation of scenarios, the taking of scenes, the process of editing and staging or drama. In addition to increasing interest in local folklore, it takes an action that starts with the family and school by forming a literacy movement based on folklore.

\section{TOBA BATAK FOLKLORE}

A. The Polite Source of Life, Not Caring for the Source of Destruction

The Toba Batak People's Story is a work of Batak Toba oral literature in the form of prose. The story was rewritten by Mangarja Pandapotan, then edited by Bugaran AntoniusSimanjuntak and printed in 2015 through the Publishing of the Indonesian Obor Foundation in Jakarta. The story of this folklore is taken and quoted indirectly fromSimanuntak [5].The summary is as follows:

At the edge of a forest were three men, consisting of one parent named Abarham, with two grandchildren named Naek and the Burju. After Abraham's wife died, he lived with his sonin-law's death almost simultaneously, so he was the one who kept his two little grandchildren. The grandfather was diligent in teaching his grandchildren to read the Bible, sing, and pray daily. After the two, grandchildren grew older, they both looked different.Naek is always many requests but the Burju always according to what his grandfather said. To the extent that the grandfather changed the name in Naek to Angat, which means warm. There are several stories depicted in this folklore. How has a concern with helping human beings and to theirparents who are sick, while Angat does not care.Also, there is a story when they are both exhausted looking for wood because of the dry season and meet an old man who asked for help to find water. Because the Burju intends to help, then there is only God help thatdirectly find water sources with the requirements must be able to answer questions. While Angat does not care about the ban.Nevertheless,Burju always begged that Angatbe free from various problems. After that, they are given a handkerchief of a wealth of 
resources and a handkerchief that can cure all kinds of diseases with the requirements should if will result in the wealth given away instantaneously. The conditions for a handkerchief every time they have to be ready to help people who come to ask for help, and they should not ask for a reward first. Also, they must also always be sincere and be fair. If they do not do so, the opposite will come with a marked illness being treated increasingly hard. In the beginning, Angat is very good to give help, and almost no one comes home with disappointment, but then he changed a lot. People who come to ask for help more and more not only during the day, midnight too many come. Therefore, he intends to make an iron fence and keep two fierce dogs in front of his house so that people are afraid to come to his house. After doing so, as the pool guard said, his wealth has diminished. Farm animal's disease and rice in rice fields eaten by caterpillars. At last, the house was burned and all its contents. Unlike Burju fulfills all the requirements that the pool guard says. All she treated healed and he never asked for a reward. He also at no time the person who asks to be treated, day or night. All the sick people recovered healed, which ultimately delivered various kinds of gratitude to him.

One day, the daughter of a king girl in her village was ill unable to speak. The king became troubled because all the physicians who were called to treat nothing succeeded. Finally, the king made the declaration and affixed to the people's houses containing. Whoever could cure the princess, would be given a gift that if still a virgin were the king's son-in-law and would be the successor to the king.Angat reads the note, then came his evil intentions. He went to the Burju's house and pretended to be sick and begged him to treat hair. Gladly Burju is willing and takes her handkerchief. He intended to remove the handkerchief to the body of Angat. However,suddenly,Angat grabs the handkerchief from the hands of Burju. Angat runs to the king's house and declares that he can heal the princess. The king is very happy to welcome him and invitesto start to cure. Angat removes the handkerchief to the forehead and neck of the princess. It turned out that the disease of the daughter grew, and her eyes became blind. The king was very angry and ordered to arrest and beat Angat and ordered to be put in jail. The handkerchief was confiscated and held by the king. God still blesses the Burju, and his fortune remains, while the Anger suffers and dies in custody.
B. The Value and Meaning of Toba Batak

Folklore The Polite Source of Life, Not Caring

for the Source of Destruction

From the folklore above, based upon the results of interviews conducted from several informants then categorized the value and meaning that serve as a source of character education value is as follows:

\section{1) Charge}

The courtesy in the Toba Batak folklore is depicted from the manners of the ever-polite Burju in touch with other people, whether it is his grandfather who raised him and the peoplehe helped. It is this polite nature that makes him successful in living.

\section{2) Concern}

In the Toba Batak, folklore described how the Burju has a concern with helping others among others to the parents who are sick, while his brother Angat did not care. Also, there is a story, they both exhausted while looking for wood because of the dry season and meet an old man who asked for help to find water. Because the Burju has a caring attitude towards others, he does not hesitate to help the parent. With this nature, there is only God's help given to the Burju as he is always given the ease and the abundant sustenance.

\section{3) Obedient to Parents}

In almost every Toba Batak folklore, there always value obedient to parents. The parent's religiosity in the Toba Batak community is rooted in their culture by placing the parent as a highly respected party until it is termedmulajadinabolonwhich means the parent is the incarnation of God on earth [6]. Because there are parents, children can succeed in their lives. Even the concept of a child for parents is very important with termed asanakkokin do hamaraon in ahuwhich means my son is my treasure [7]. Thus the Batak people strive to educate their children well. It is only natural that children in Toba Batak society are expected to obey their parents. In Toba Batak, folklore is described how the character named the Burju has obedience to the parents so that he can succeed in his life.

\section{4) Not Arrogant or Humble}

The character of arrogant, high-hearted and haughty nature that is considered not good. All 
Toba Batak folklore always describes a pleasant character and who is not. In Toba Batak, folklore described the requirement that the handkerchief given can be used as a source of wealth and cureall kinds of diseases. It is said that the requirement for such a handkerchief to be able to function, which use it should not be arrogant. If they do not have these unkind qualities, the wealth given will be instantaneous.

\section{5) Helping Others}

Some of the stories in the Toba Batak folklore depict when the Burju has a concern for helping the sick parents, while his brother does not care. Also, there is a story when they are both exhausted when looking for wood because of the dry season and meet an old man who asked for help to find water. Because Burju often helps others with sincerity, there is God's always help him in addition to being facilitated to help others. $\mathrm{He}$ is also given anabundant fortune.

\section{6) Sincere}

In the Toba Batak, folklore depicted how the Burju has a sincere and humble nature that always seeks to help others without discriminating against them and tirelessly. If Burju does not possess such traits, it is described as his brother treating the princess of the disease he is treating even harder.

\section{7) Be fair}

The just nature is depicted in the Toba Batak folklore as Burju does not discriminate against anyone who asks for help to be treated. If he does not have this fairnature, of course, the disease will be treated more and more hard.

\section{8) No Strings Attached}

As illustrated in this folklore, when the Burju treats anyone who asks for his help, he is tireless. Burju never asked for wages before. He also at no time rejects people who ask for treatment. Every sickperson recovered whenhe treated. In the end, he did get much gratitude that came to her.

\section{CONCLUSION}

The revitalization of the Toba Batak folklore The Polite Source of Life, Not Caring for the Source of Destruction seen from the value of meaning described above, it has fulfilled two classifications of 4 (four) character configurations based on the psychosocial and sociocultural context in the implementation of education policy of the Ministry of National
Education namely: (1)spiritual and emotional development,which includes the core character: religious, honest, responsibility, social care, and caring environment; (2)intellectual developmentthat includes the core character: intelligent, creative, avid read, curiosity; (3) sports and kinesthetic(physical and kinesthetic development)which include the core character: healthy and clean; (4)affective and creativity developmentwhich includes the core character: care and cooperation.While 2 (two) classifications of character configuration value and meaning of character education based on Toba Batak folklore are: (1) Hearts that include religious, honest, responsibility, social care, and care for the environment. In the classification of character configurations contained in the Toba Batak folklore are: polite, caring, obedient to the elderly, not arrogant (humble); (2) Flavor and Karsa which include: care and cooperation. In character configurations classified as this type according to the Toba, Batak folklore is: helping others, sincere, fair and unconditional.

Thus, much folklore contains character education values that have conformity to the education policy of the Ministry of National Education. Also, folklore is useful as a means to guide children to behave well. In folklore contains much advice or advice that can be used as life lessons.

\section{REFERENCES}

[1] Saefuddin, Koran Terbit Top, Edisi ke 68/Th III 23 April-4 Mei 2016.

[2] D. E. Papalia, et all., Human Development (Psikologi Perkembangan). Jakarta: Kencana, 2008.

[3] J. A. Brewer, Introduction to Early Early Chilhood Education Preschool through Primary Grades. USA: Pearson Eduaction, Inc, 2007.

[4] T. Lickona, Educating of Character, diterjemahkan oleh Wamaungo. Jakarta: Bumi Aksara,1991.

[5] S. Simanjuntak, Folklor Batak Toba, Bungaran Antonius Simanjuntak ed., Jakarta: Yayasan Pustaka Obor Indonesia, 2015, pp. 203-207.

[6] J. C. Vergouwen, Masyarakat dan Hukum Adat Batak Toba. Yogyakarta: LKIS, 1986.

[7]. R. Baiduri, "Paradoks Perempuan Batak Toba: Suatu Penafsiran Hermeneutik terhadap Karya Sastra Ende Siboru Tombaga", Mimbar, vol. 31, No. 1, pp. 51-60, Juni, 2015 
